\title{
The Relationship Of Hygine Sanitation, Sanitation Facilities and Exchanger Actions With Fly Density Levels in Dining House in Meulaboh City
}

\author{
${ }^{1}$ Ihsan Murdani, ${ }^{2}$ Zakiyuddin, ${ }^{3}$ Jun Musnadi, ${ }^{4}$ Muhammad Iqbal Fahlevi, 5 Maiza Duana \\ ${ }^{1}$ Public Health Faculty, Teuku Umar University, Meulaboh, Indonesia \\ 2 Public Health Faculty, Teuku Umar University, Meulaboh, Indonesia \\ 3 Public Health Faculty, Teuku Umar University, Meulaboh, Indonesia \\ ${ }^{4}$ Public Health Faculty, Teuku Umar University, Meulaboh, Indonesia \\ ${ }^{5}$ Public Health Faculty, Teuku Umar University, Meulaboh, Indonesia \\ Coresponding author: Ihsan Murdani, Email: ihsanmurdani@utu.ac.id
}

\begin{abstract}
It is known that the number of restaurants in the city of Meulaboh there are 66 restaurants. After observing the eating houses in the town of Meulaboh, can be in the know that sanitation eat less qualified home health such as ownership of the means of waste disposal, garbage disposal facilities, hand-washing facilities, washing facilities appliance. The purpose of this study is the relationship Sanitatl : ion Hygiene, sanitation facilities, and action handlers Density With Flies On Eating In the city of Meulaboh. This research is an analytic method with cross sectional design. This research was conducted in the city of Meulaboh implemented Johan Pahlawan sub-district of West Aceh on 7 November to 5 December 2016, with a population of 66 homeowners and their eating of food handlers, the sampling technique is used total sampling method and analyzed by univariate and bivariate using chi-test square. The results showed that there is significant correlation between sanitation hygiene factors (P.Value $=0.006<a=0.05$ ), sanitary facilities $(P$.Value $=0.025<a=0.05)$, action handlers $(P$.Value $=0.026$ $<a=0.05$ ) with the density of flies in the restaurant in the city of Meulaboh. It was concluded that there is significant correlation between the factors of hygiene sanitation, sanitation facilities, action handlers with the density of flies in the restaurant in the city of Meulaboh. with the density of flies in the restaurant in the city of Meulaboh to achieve a state of healthy foods that are not exposed to flies and protected from various diseases caused by flies.
\end{abstract}

\section{ARTICLE INFORMATION}

Submitted: $10 / 11 / 2020$

Revised: $19 / 11 / 2020$

Accepted: 28/11/2020

Published Online: 30/11/2020

Keywords:

Flies Density

Handling Actions

Sanitary Hygiene

Sanitation Facilities

How to cite this article: Murdani, I., Zakiyuddin., Musnadi, J., Fahlevi, M. I., Duana, M. (2020). The Relationship of Hygine Sanitation, Sanitation Facilities and Exchanger Actions with Fly Density Levels in Dining House in Meulaboh City. JNS : Journal of Nutrition Science, 1(2)

\section{Introduction}

Food is a material that enables humans to grow and develop and be able to move and maintain their body condition. For this reason, foodstuffs or what we usually call food need to pay attention to the type and quality so that they are safe for consumption. Food is generally composed of water, protein, carbohydrates, fats, vitamins, fiber and minerals. These components play an important role in giving character to food both physical, chemical and functional properties. With advances in science and technology in the field of food, various types of food can be made more durable, more attractive, safer, tastier and more practical for consumers (Nur'an, 2013).

Based on preliminary data from the profile of the West Aceh Health Office, the number of diarrhea sufferers in West Aceh 2013 was 537 cases, in 2014 there were 572 cases of diarrhea sufferers. 
Based on the preliminary data collection that researchers have obtained at the Johan Pahlawan Health Center, the number of diarrhea sufferers in 2014 was 540 cases, of which 290 male sufferers and 250 female sufferers. In 2015 there were 785 cases, of which 426 male cases and 359 female sufferers. Meanwhile, in 2016 there were 63 cases in January, 80 cases in February, 43 cases in March, 59 cases in April and 71 cases in June. Meanwhile, the number of restaurants in the city of Meulaboh according to Johan Pahlawan Health Center is 66, 23 (34.8\%) restaurants that meet the requirements and 43 $(65.2 \%)$ restaurants that do not meet the requirements. (Puskesmas, 2015)

The hygiene of the restaurant is still low in terms of its location close to the main road, automatically there is a lot of dust and pollution that can be directly related to the restaurant. The facilities and facilities at the restaurant are still lacking, there is no sink for food handlers. Food handlers are still less aware of doing PHBS (Clean and Healthy Living Behavior). If environmental factors are not healthy because they are contaminated with germs and accumulate with unhealthy human behavior, then diarrhea transmission can easily occur. (Fitri, 2013). Good hygiene and sanitation are important factors in preventing diseases caused by a bad environment, such as diarrhea (Yarmaliza, 2018).

Based on the results of preliminary observations, the fact that the problem in restaurants in the city of Meulaboh is sanitation facilities in the form of food cabinets that are displayed in restaurants and most of them are not closed. Even if there is, the cover is only a thin curtain used cloth that is rarely closed, especially when guests are busy. Because of this, some flies can easily contaminate the peddled food. With the increasing demand for food provided outside their homes or boarding houses, the products provided by restaurants located in the city of Meulaboh are very important. The restaurant is one of the places frequently visited by office workers, workers around the restaurant, and employees around the city of Meulaboh, even ordinary people who like to eat outside the home because they think it is more practical. A restaurant that operates in the business of providing food must be guaranteed health and safety.

This can be realized if it is supported by the high level of knowledge of food handlers about the dangers that will be caused by the poor quality of the sanitation facilities provided at each restaurant.

There are 66 restaurants in Meulaboh city. After conducting observations at restaurants in the city of Meulaboh, it can be seen that the environmental sanitation of the restaurant does not meet health requirements such as ownership of waste disposal facilities, waste disposal facilities that are not closed and placed beside a shelf, hand washing facilities where soap is not available and even using a basin. as a place for washing hands, a means of washing tools that do not use running water. With the quality of sanitation facilities like this, there are many complaints raised by buyers and local residents, including the smell caused by poorly managed garbage, lots of flies due to the provision of inappropriate trash cans, namely in restaurants only trash bins are not equipped. with the lid, there is no provision for washing hands equipped with soap for visitors to the restaurant.

\section{Restaurants}

According to the Decree of the Minister of Tourism, Post and Telecommunications No.KN.73 / PVV105 / MPPT-85 concerning Restaurant Business Regulations, in this regulation what is meant by the food service business is a business that provides commercially managed food and beverage services.

\section{Definition of Food Hygiene and Sanitation}

Hygiene and sanitation is an action or effort to improve hygiene and health through early maintenance of each individual and environmental factors that influence it, so that individuals avoid the threat of disease-causing germs (MOH, 1994).

\section{Food Handlers}

Food handlers are personnel who are directly related to food and beverages and their equipment from the stages of preparation, processing, packaging, transportation to presentation (Decree of the Minister of Health RI No.715 / Menkes / SK / V / 2003). 2.3 Flies

Flies are mechanical vectors, namely flies act as passive transfer devices with the understanding that pathogenic microorganisms do not undergo any changes in the body of the fly, but only stick to the fly's body such as on 
the wings, legs, other body parts, vomit and faeces (Widyati and Yuliarsih, 2002).

Currently there are around $\pm 60,000$ 100,000 species of flies, but not all species need to be monitored because some of them are not dangerous to public health (Santi, 2001).

\section{Types and Research Design}

This type of research is analytical research, namely research that explains the relationship between variables. The method used is cross sectional. Cross sectional research is a study to study the dynamics of the correlation between risk factors and effects, by approaching, observing or collecting data at once (point time approach) (Notoadmodjo, 2010).

\section{Location and Time of Research}

This research was conducted in the city of Meulaboh, Johan Pahlawan District, West Aceh Regency on November 7 - December 29, 2016.

\section{Population and Sample Population}

Population is the whole object under study (Notoatmodjo, 2010). The population in this study were 66 restaurant owners and food handlers in the city of Meulaboh, Johan Pahlawan District, West Aceh Regency in 2016.

\section{Sample}

According to Arikunto (2006), if the total population is less than 100 , the sample taken is the whole population because the larger the sample is taken, the better the research results. So the technique used is to use the total sampling method, which is taking the entire population to be sampled, namely all food traders in the city of Meulaboh, Johan Pahlawan subdistrict, namely 66 houses, it can be seen in Table 1 below:

The results of the calculation of frequency and percentage based on hygiene sanitation

Table 1. Frequency Distribution Based on Sanitary Hygiene with Density Levels of Flies in Restaurants in Meulaboh City

\begin{tabular}{lcc}
\hline \multicolumn{1}{c}{ Hygiene Sanitation } & f & \% \\
\hline Good & 29 & 43,9 \\
Not good & 37 & 56,1 \\
\hline Total & 66 & 100 \\
\hline
\end{tabular}

Source: Primary Data
Based on Table 4.4, it can be seen that respondents with poor sanitation hygiene were 37

respondents $(56.1 \%)$. Meanwhile, respondents with good sanitation hygiene were 29 respondents $(43.9 \%)$.

The results of frequency and percentage calculations based on sanitation facilities can be seen in Table 2 below:

Table 2. Frequency Distribution Based on Sanitation Facilities with Flies Density Levels in Restaurants in Meulaboh City

\begin{tabular}{lcc}
\hline $\begin{array}{c}\text { Sanitation } \\
\text { Facilities }\end{array}$ & f & \% \\
\hline Qualify & 19 & 28,8 \\
Not eligible & 47 & 71,2 \\
\hline Total & 66 & 100 \\
\hline
\end{tabular}

Source: Primary Data

Based on Table 2, it can be seen that the respondents whose sanitation facilities did not meet the requirements were 47 respondents $(71.2 \%)$. Meanwhile, 19 respondents $(28.8 \%)$ met the requirements of sanitation facilities.

The results of the calculation of the frequency and percentage based on the actions of the handlers can be seen in Table 3 below:

Table 3. Frequency Distribution Based on Handling Actions with Density Levels of Flies in Restaurants in Meulaboh City

\begin{tabular}{lcc}
\hline $\begin{array}{c}\text { Handler's } \\
\text { Actions }\end{array}$ & f & \% \\
\hline There is & 22 & 33,3 \\
There is no & 44 & 66,7 \\
\hline Total & 66 & 100 \\
\hline
\end{tabular}

Source: Primary Data

Based on Table 3, it can be seen that the respondents who did not have a touch of action were 44 respondents (66.7\%). while respondents who had the act of being a touch were 22 respondents (33.3\%).

The results of calculating the frequency and percentage based on the level of fly density can be seen in Table 4 below:

\section{Table 4. Frequency Distribution Based on Flies Density Levels in Restaurants in Meulaboh City}


Available at http://jurnal.utu.ac.id/JNS/article/view/2766

\begin{tabular}{lcc}
\hline $\begin{array}{c}\text { Density } \\
\text { Flies }\end{array}$ & f & \% \\
\hline Low & 19 & 28,8 \\
Moderate & 20 & 30,3 \\
Solid & 27 & 40,9 \\
\hline Total & 66 & 100 \\
\hline
\end{tabular}

Source: Primary Data

Based on Table 4, it can be seen that respondents with a solid fly density level were 27 respondents $(40.9 \%)$, respondents with moderate fly density levels were 20 respondents $(30.3 \%)$, and respondents with light fly density levels were 19 respondents (28.8\%)

Relationship between Sanitation Hygiene Factors and Flies Density Levels

Tabel 5 Sanitation Hygiene Factors related to Flies Density Levels in Restaurants in Meulaboh City

\begin{tabular}{|c|c|c|c|c|c|c|c|c|c|}
\hline \multirow{3}{*}{$\begin{array}{l}\text { Hygi } \\
\text { ene } \\
\text { Sanit } \\
\text { ation }\end{array}$} & \multicolumn{6}{|c|}{ Fly Density Level } & \multirow{2}{*}{\multicolumn{2}{|c|}{ Total }} & \multirow{3}{*}{$\begin{array}{c}P . \\
\text { Val } \\
\text { ue }\end{array}$} \\
\hline & \multicolumn{2}{|c|}{ Low } & \multicolumn{2}{|c|}{$\begin{array}{c}\text { Modera } \\
\text { te }\end{array}$} & \multicolumn{2}{|c|}{ Solid } & & & \\
\hline & $\mathbf{n}$ & $\%$ & $\mathbf{n}$ & $\%$ & & $\%$ & $\mathbf{f}$ & $\%$ & \\
\hline Good & 14 & $\begin{array}{l}48 \\
, 3\end{array}$ & 5 & $\begin{array}{l}17 \\
, 2\end{array}$ & 10 & $\begin{array}{l}34 \\
, 5\end{array}$ & 29 & $\begin{array}{c}10 \\
0\end{array}$ & 0,0 \\
\hline $\begin{array}{l}\text { Not } \\
\text { good }\end{array}$ & 5 & $\begin{array}{r}13 \\
, 5\end{array}$ & 15 & $\begin{array}{l}40 \\
, 5\end{array}$ & 17 & $\begin{array}{c}45 \\
, 9\end{array}$ & 37 & $\begin{array}{c}10 \\
0\end{array}$ & 25 \\
\hline
\end{tabular}

Source: Primary Data

Table 5 above can be seen that from a total of 29 respondents who had good sanitation hygiene, most of the respondents had a good fly density level of $14(48.3 \%)$, and from a total of 37 respondents with poor sanitation hygiene, most of the respondents had moderate fly density levels as much as 15 $(40.5 \%)$, while the respondent's density level of solid flies was 17 (45.9\%). So it can be concluded that there is a significant relationship between hygiene sanitation and the level of fly density.

Based on this, according to the results of statistical tests, the value of P. value $=0.006$ and this is smaller than $a=0.05$ ( $P$. value $=$ $0.006<a=0.05$ ) so that there is a significant relationship between hygiene sanitation and density. flies in restaurants in Meulaboh City.

Relationship between Sanitation Facility Factors and Flies Density Levels
Table 6 Sanitation Facility Factors related to Flies Density Levels in Restaurants in Meulaboh City

\begin{tabular}{|c|c|c|c|c|c|c|c|c|c|}
\hline \multirow{3}{*}{$\begin{array}{l}\text { Sanit } \\
\text { ation } \\
\text { Facili } \\
\text { ties }\end{array}$} & \multicolumn{6}{|c|}{ Fly Density Level } & \multirow{2}{*}{\multicolumn{2}{|c|}{ Total }} & \multirow{3}{*}{$\begin{array}{l}\text { P.Va } \\
\text { ue }\end{array}$} \\
\hline & \multicolumn{2}{|c|}{ Low } & \multicolumn{2}{|c|}{$\begin{array}{c}\text { Moder } \\
\text { ate }\end{array}$} & \multicolumn{2}{|c|}{ Solid } & & & \\
\hline & n & $\%$ & $n$ & $\%$ & $\mathbf{n}$ & $\%$ & $\mathbf{f}$ & $\%$ & \\
\hline Qualif & 1 & 52 & 4 & 21 & 5 & 26 & 1 & 1 & 0,0 \\
\hline y & 0 & 6 & & 1 & &, 3 & 9 & $\begin{array}{l}0 \\
0\end{array}$ & \\
\hline $\begin{array}{l}\text { Not } \\
\text { eligibl } \\
\text { e }\end{array}$ & 9 & $\begin{array}{l}19 \\
1\end{array}$ & $\begin{array}{l}1 \\
6\end{array}$ & $\begin{array}{l}34 \\
, 0\end{array}$ & $\begin{array}{l}2 \\
2\end{array}$ & $\begin{array}{l}46 \\
8\end{array}$ & $\begin{array}{l}4 \\
7\end{array}$ & $\begin{array}{l}1 \\
0 \\
0\end{array}$ & \\
\hline
\end{tabular}

Source: Primary Data

Table 6 above can be seen that out of a total of 19 respondents who have good sanitation facilities, most of the respondents with the density level of flies meet the requirements of $10(52.6 \%)$, and of a total of 47 respondents, sanitation facilities do not meet the requirements of most respondents density level There were $16(34.0 \%)$ medium flies, while the respondents with the density level of solid flies were $22(46.8 \%)$. So it can be concluded that there is a significant relationship between sanitation facilities and the level of fly density.

Based on this, according to the results of statistical tests, the value of $P$. value $=0.025$ and this is less than $a=0.05$ ( $P$. value $=0.025$ $<a=0.05)$ so that it is described that there is a significant relationship between sanitation facilities and density. flies in restaurants in Meulaboh City.

The Relationship between Handling Action Factors and Flies Density Level

Table 7 Handler's Action Factors related to the density level of flies in restaurants in Meulaboh City

\begin{tabular}{|c|c|c|c|c|c|c|c|c|c|}
\hline \multirow{3}{*}{$\begin{array}{l}\text { Handl } \\
\text { er's } \\
\text { Actio } \\
\text { ns }\end{array}$} & \multicolumn{6}{|c|}{ Fly Density Level } & \multirow{2}{*}{\multicolumn{2}{|c|}{ Total }} & \multirow{3}{*}{$\begin{array}{c}\text { P.Val } \\
\text { ue }\end{array}$} \\
\hline & \multicolumn{2}{|c|}{ Light } & \multicolumn{2}{|c|}{$\begin{array}{c}\text { Moder } \\
\text { ate }\end{array}$} & \multicolumn{2}{|c|}{ Solid } & & & \\
\hline & $\mathbf{n}$ & $\%$ & $\mathbf{n}$ & $\%$ & $\mathbf{n}$ & $\%$ & $\mathbf{f}$ & $\%$ & \\
\hline There & 1 & 50 & 5 & 22 & 6 & 27 & 2 & 1 & $\mathbf{0 , 0}$ \\
\hline is & 1 & , 0 & &, 7 & &, 3 & 2 & $\begin{array}{l}0 \\
0\end{array}$ & 26 \\
\hline There & 8 & 18 & 1 & 34 & 2 & 47 & 4 & 1 & \\
\hline is no & & , 2 & 5 &, 1 & 1 &, 7 & 4 & $\begin{array}{l}0 \\
0\end{array}$ & \\
\hline
\end{tabular}

Source: Primary Data 
Table 7 above can be seen that from a total of 22 respondents who have handcuff actions, most of the respondents have 11 $(50.0 \%)$ of the fly density level, and out of a total of 44 respondents, there are no most respondents with moderate fly density as much as $15(34.1 \%)$, while respondents with the density level of solid flies were $21(47.7 \%)$. So it can be concluded that there is a significant relationship between handler actions and the density of flies.

Based on this, in accordance with the results of statistical tests, the value of $P$. value $=0.026$ and this is smaller than $a=0.05$ ( $P$. value $=0.026<a=0.05$ ) so that it is described that there is a significant relationship between the handlers' actions and the level of density. flies in restaurants in Meulaboh City.

\section{Discussion}

\section{Relationship between Sanitation Hygiene Factors and Flies Density Levels in Restaurants in Meulaboh City}

Based on the results of the research conducted by the researchers, the respondents of good sanitation hygiene and the level of light fly density because the restaurant already has good sanitation hygiene, while the respondents of sanitation hygiene are not good and the level of fly density is because the restaurant has provided clean water even though it is still do not have a good waste management place and the respondent is heavy with the density level of flies because the restaurant does not have good fly sanitation hygiene such as still poor water facilities, the location is still very close to the landfill.

Good environmental hygiene is an important thing in life to stay healthy, so that you can avoid various diseases due to infections caused by an unsanitary environment (Yarmaliza, Farisni, \& Fitriani, 2019). Then the density of flies that is dense is on National Street, Imam Bonjol Street and on Jalan Daud Dariah.

This study is in line with the research of Kuswanti, F (2013) where there is a relationship between hygiene sanitation and the incidence of diarrhea at PT. $X$ in Karanganyar with a value of $a=0.039$. This research is also in line with the research of Sembiring, et, al (2013) where there is a relationship between hygiene sanitation, food management and fly density in the traditional market of Pematangsiantar horas market.

\section{Relationship between Sanitation Facility Factors and Flies Density Levels in Restaurants in Meulaboh City \\ Based on the results of the research} conducted by the researchers, the respondents of sanitation facilities met the requirements and the density level of light flies because the restaurant already had good and complete sanitation facilities, while the respondents of sanitation facilities did not have and were having moderate levels of fly density because the restaurant had provided a washing place running water, washing hands that use faucets and heavy respondents because the restaurant does not have good sanitation facilities such as a kitchen that is not yet proper and does not have a place and hand soap for customers.

This study is in line with Julhija's research (2015) where there is a relationship between sanitation facilities and the level of fly density in the high school canteen (SMA) with a value of $a=$ 0.000 in Perbaungan District in 2013. This research is also in line with Prasetya's research (2012) where there is a relationship sanitation facilities in restaurants in the Gorontalo area with a value of $a=0,000$

Relationship between Handling Action

\section{Factors and Flies Density Levels in Restaurants in Meulaboh City}

Based on the results of the research conducted by the researchers, the respondents of sanitation facilities met the requirements and the density level of light flies because the restaurant already had good and complete sanitation facilities, while the respondents of sanitation facilities did not have and were having moderate levels of fly density because the restaurant had provided a washing place running water, washing hands that use faucets and heavy respondents because the restaurant does not have good sanitation facilities such as a kitchen that is not yet proper and does not have a place and hand soap for customers.

This study is in line with Sari's (2012) research that there is a relationship between handler actions and food management with a value of $a=0.000$ in Rantau Utara District, Labuhan Batu Regency.

\section{Conclusion}

1. There is a significant relationship between hygiene sanitation and the level of fly density at restaurants in Meulaboh City as evidenced by the value (Pvalue $=0.006<a=0.05$ ) .

2. There is a significant relationship between sanitation facilities and the level of fly density 
at restaurants in Meulaboh City as evidenced by the value (Pvalue $=0.025<a=0.05$ ) .

3. The existence of a significant relationship between handler actions and the level of fly density in restaurants in Meulaboh City as evidenced by the value (Pvalue $=0.026<a$ $=0.05$ ).

\section{Suggestions}

1. It is recommended to restaurant owners to always maintain good and correct hygiene and sanitation facilities to create a healthy food condition so that flies do not infest it and avoid various diseases caused by flies.

2. It is advisable for health workers to provide information to the restaurant owner or by giving brochures that tell about healthy food.

3. For further researchers, it is hoped that they can develop this research with different tests.

4. Jasmine Prediabetes Group is better in weight loss than Rose Prediabetes Group with a comparison of $P$ value $(0.028$ $<0.045)$, this can be interpreted as jogging is more influential than a relaxed walk in weight loss.

\section{References}

Arikunto. S. 2006. Research Procedures for a Practical Approach. Jakarta: Rineka Cipta.

Azwar, A, 1989, Introduction to Environmental Health Sciences, Mutiara Sumber Widya, Jakarta.

Ahmadi, 1999. Social Psychology. Rineka Cipta: Jakarta

Agustina, Pambayun, 2010. Hygiene and Sanitation for Traditional Snack Food Traders in Elementary Schools in Demang Lebar Daun Sub-District, Palembang. Journal of Public Health, Volume 1 No. March 1, 2010. Faculty of Public Health, Sriwijaya University.

Depkes RI, 1992, Law no. 23, About Health, Jakarta.

_ _ _ _1994. Guidelines for the Management and Health of School Food Stalls. Jakarta 1995. Technical Guidelines for Fly Control. MOH RI. Jakarta

----------, 2001, Collection of Food Health Course Modules for Food and Beverage Entrepreneurs, Message Foundation Publisher, Jakarta.
Health of the Republic of Indonesia Number 715 / Menkes / SK / V / 2003 concerning the Hygiene Requirements for Jasaboga Sanitation. Jakarta.

2003. Decree of the Minister of Health of the Republic of Indonesia No. 1098 / Menkes / SK / VII / 2003 concerning Sanitation Hygiene Requirements for Restaurants and Restaurants, Jakarta.

2004. Food and Beverage Sanitation Hygiene (HSMM). Health Inspector Academy Handbook. Jakarta. - 2004. Habits of Life Flies. Journal of Health.

2006. Personal Hygiene. Jakarta.

--.---.-. 2007. Food Administration at the Hospital. Directorate General of Community Health Nutrition. Ministry of Health of the Republic of Indonesia.

West Aceh Health Office. 2015. Health Profile of Aceh Barat. West Aceh

Fardianz, 2001. Food and Nutrition Science: Industrial Technology and International Trade. Sagung Seto: Jakarta

Fathonah, S. 2005. Food Hygiene and Sanitation. Semarang: UNNES Press

Fitri, 2013. The Relationship Between Canteen Hygiene With Diarrhea Incidence of Food Handlers Pt. X In Karanganyar. sebelas Maret University

Julhija. 2015. Hygiene sanitation and knowledge, attitudes and actions of sellers on fly density in the school canteen in Sidamanik sub-district. University of Northern Sumatra

HAKLI (Association of Environmental Health Experts). 2009. Fly Control. http://www.hakli.org.

Ministry of Health. 2013. Principles of Food Hygiene and Sanitation. Jakarta: Ministry of Health RI

Kepmenkes RI. 2003. Decree of the Minister of Health of the Republic of Indonesia Number 1098 / MENKES / SK / VII / 2003 concerning Sanitation Hygiene Requirements for Restaurants and Restaurants. Jakarta.

Khomsan, 2004, Food and Nutrition for Health, PT Grafindo Persada, Jakarta. 
Kuswanti, F. 2013. The Relationship Between Canteen Hygiene and Diarrhea at Food Handlers Pt. X In Karanganyar. sebelas Maret University

Nugroho, 2011. Hygiene Conditions of Food Handlers and Canteen Sanitation at SMA 15 Surabaya. Airlangga University.

Nur'an. 2013. The Concept of Health Science Education, Mutiara Sumber Widya, Jakarta.

Nurmaini. 2001. Identification of Vectors and Nuisance Animals and Simple Control of Anopheles Aconitus. Faculty of Public Health. University of Northern Sumatra.

Notoatmodjo, S. 2003. Education and Health Behavior. Rineka Cipta. Jakarta.

--------..- 2007. Public Health (Science and Arts), Jakarta: Rineka Cipta. 2010. Health Research Methodology. Jakarta: PT Rineka Cipta.

Purnawijayanti, H, 2001, Sanitation, Hygiene and Work Safety in Food Management, Kanisius, Yogyakarta.

King. 2008. Food Hygiene and Sanitation. http // gmpg.org. Jakarta

Prasetya. 2012. Hygiene and sanitation facilities for restaurants in the city of Gorontalo. Journal of Science and Technology Volume 6 Number 5.

Santi, Devi Nuraini. 2001. Fly Control Management. USU digital library.Medan.

Sari. 2012. Hygiene Sanitation Food Management and Food Handling Behavior in Public and Private High
School Canteen in Rantau Utara District, Labuhan Batu Regency, 2012. University of North Sumatra

Sarudji, Didik. 2010. Environmental Health. The work of Putra Darwati. Bandung.

Soemirat Slamet, J. 2009. Environmental Health. Yogyakarta: Gajahmada University Press.

Sembiring, et, al. 2013. Hygiene and sanitation management of food and fly density in the traditional market, Pematangsiantar market. University of Northern Sumatra

Todar, K, 2012. Staphylococcus aureus and Staphylococcal Disease. USA: Wiscosin, Madison.

Yarmaliza. (2018). The Effects of Improper Household Waste Management by Mothers on the Genesis of Diarrhea in Toddlers. Journal of International Dental and Medical Research, 11(3), 1053-1057.

Yarmaliza, Y., Farisni, T. N., \& Fitriani, F. (2019). Epidemiological evaluation: analysis of mother's characteristics, against the incidence of diarrhea in toddlers. International Journal of Medical Science and Clinical Research, 1(4), 1519.

Winarsih. 2012. Sanitation Knowledge and Its Application. Semarang: Various Sciences.

Widyati Dan Yuliarsih, 2002. Hygiene and General Sanitation and Hospitality. Gramedia: Jakarta

WHO. 2007. Food Safety and Foodborne Illness, World Health Organization (WHO). 